
\title{
R Research S Suare \\ Knowledge, attitudes, practices, and the effects of COVID-19 among the youth in Kenya
}

Evalin Karijo ( $\square$ evalin.karijo@amref.org )

Amref Health Africa https://orcid.org/0000-0003-2737-0397

Sylvia Wamugi

Amref Health Africa

Samuel Lemanyishoe

Amref Health Africa

Jenny Njuki

Amref Health Africa

Faith Boit

Amref Health Africa

Vania Kibui

Amref Health Africa

Sarah Karanja

Amref Health Africa

Timothy Abuya

Population Council Kenya

\section{Research article}

Keywords: COVID-19, Youth, Knowledge, Attitudes, Practices, Sexual and Reproductive Health

Posted Date: January 11th, 2021

DOI: https://doi.org/10.21203/rs.3.rs-34861/v3

License: (c) (i) This work is licensed under a Creative Commons Attribution 4.0 International License.

Read Full License 


\section{Abstract}

Background: Cases of the Corona Virus Disease of 2019 (COVID-19) in Kenya have continued to increase rapidly, since the first case in the country was confirmed in March 2020. In the wake of the pandemic, the health and socio-economic challenges experienced by the youth in Kenya are likely to be elevated. We assessed knowledge, practices, perceived risk, adoption of recommended behaviour and the effects of COVID-19 among the youth in Kenya.

Methods: A cross sectional descriptive study was conducted between April $30^{\text {th }}$ to May $7^{\text {th }}, 2020$ through a combined online survey and phone interviews. A total of 2,156 youth across all 47 counties in Kenya completed the responses to the study questions. All survey responses analyzed using STATA v15 were tabulated by gender, age, and education level to generate basic descriptive tables and tested for differences by category using chi-square tests. Where applicable, linear and logistic regression analysis model was conducted using covariates such as employment status, gender, and education level.

Results: Knowledge on symptoms of COVID-19 was generally high. Female respondents were more likely to identify more symptoms correctly compared to men; $p<0.001$. However, youth reported very low levels of anyone being at risk of infection (7\%). Most youth have adopted behavior necessary to slow down the infection. There were generally very low reported levels of inability to access health services related to sexual and reproductive health. About $50 \%$ of respondents reported significant decline in income during the pandemic period, nearly a third reported living in fear while $27 \%$ reported feeling stressed.

Conclusion: There was high knowledge of COVID-19 symptoms, preventive strategies, and high adoption of preventive practices. Strategies to sustain behaviors positively adopted among young people will be critical to reduce the spread of COVID-19. Despite low reported rates of inability to access sexual and reproductive health, response measures should include strategies that facilitate continuity of services among young people. The reported social effects of the pandemic show the need for interventions to meet the health and socioeconomic needs of the youth and minimize the long-term consequences of the pandemic.

\section{Background}

Coronaviruses are a family of respiratory viruses that cause common cold, Middle East Respiratory Syndrome (MERS) and Severe Acute Respiratory Syndrome (SARS) [1-5]. The coronavirus disease of 2019 (COVID-19) was isolated and referenced as severe acute respiratory syndrome coronavirus 2 (SARSCoV-2)[6]. The disease has since become a global pandemic [6-8] forcing countries to implement measures to slow the spread that has impacted global economies[9]. Initial modelling studies indicated that the risk of importation to African countries was heterogeneous with countries like Egypt, Algeria, and South Africa having the highest importation risk and moderate to high capacity to respond. Nigeria, Ethiopia, Sudan, Angola, Tanzania, Ghana, and Kenya had moderate risk with variable capacity to 
respond [10]. Since then, the virus has spread to many African countries with 54 of 55 African Union Member States reporting over 100,000 cases and 3,100 deaths by May 2020[11].

In Kenya, since the announcement of its first case of COVID-19 in early March[12], there was a rise in COVID-19 cases, estimated at 320 at the start of study rising to 607 within a week [13]. In response, the Kenyan government implemented a mix of public health response measures, including messaging to create awareness on preventive measures, such as use of masks, practicing hand hygiene and social distancing. Additionally, there were international travel bans and cessation of movements in and out of areas that exhibited high rates of infections. The government also implemented a dusk to dawn curfew in all 47 counties and shut down public places including schools, churches, and other social gatherings, to slow down the spread of the virus.

Despite these measures and given the risk of poor outcomes among older persons and those with underlying conditions [6], young people are likely to contribute to the spread of the virus, given their high population and mobility. For example, seventy-five percent of the 47.6 million Kenyans (35.7 million) is under the age of 35 years, while young people aged 18-34 years constitute $29 \%$ (13.7 million) of the total population[14]. Although young people presents an opportunity to drive the country's economy, they face numerous health and socio-economic challenges [15]. For example, adolescents in Kenya experience poor sexual and reproductive health (SRH) outcomes [16]. The 2014 Kenya Demographic Health Survey show that one in every five teenage girls between the ages of 15-19 has begun childbearing, while contraceptive prevalence rate among sexually active unmarried girls aged $15-19$ years is $49 \%$ and $64 \%$ among those aged 20-24 years[17]. The country's HIV estimates showed that young women aged 15-24 accounted for a third of all new HIV adult infections[18]. Other than poor health outcomes, the youth unemployment rate is estimated at $35 \%$, compared to the overall national unemployment rate of $10 \%$. Furthermore, $80 \%$ of unemployed Kenyans are below 35 years old[19].

Based on experiences of previous outbreaks in Africa, such as Ebola, failure to contain the virus is likely to overwhelm health systems and increase mortality from malaria, HIV/AIDS, and tuberculosis [20, 21]. The pandemic is also likely to strain access to youth friendly services and SRH information. Shortages of medications such as contraceptives, antiretroviral drugs for HIV/AIDS and antibiotics to treat Sexually transmitted infections (STIs), due to disruptions in supply chain is likely to affect women and girls[22]. As governments provide solutions to fight the pandemic, its impact on a country's health systems and the economy at large needs to be considered from the outset to avoid disruption. To guide immediate pandemic response, we conducted a study to establish knowledge, practices, perceived risk, adoption of recommended behavior and the effects of COVID-19 among the youth in Kenya.

\section{Methods}

This was a cross sectional descriptive study conducted from April $30^{\text {th }}$ to May $7^{\text {th }}, 2020$ using a combined online survey and phone interviews. Out of 3,414 youth who were targeted for the study, a total of 2,156 youth aged $18-35$ across all 47 counties in Kenya completed the survey or phone interviews 
fully. We with respondents drawn from Amref Health Africa's Y-ACT, Youth in Action platform, other stakeholders' youth platforms, youth-referrals via SMS messaging and social media. The study was conducted under Y-ACT, Youth in Action's national network of youth, an initiative of Amref Health Africa established in 2017. Y-ACT represents the voice of young people aged 18-35 years, advocating for policy changes on SRH and Gender Equality. Over the last three years, Y-ACT has created and mobilized an online advocacy movement of over 3,414 youth advocates across all 47 counties in Kenya. Y-ACT has catalyzed key policies in Kenya including the Adolescent SRH Policy in Nairobi County, gender protection policy in Kilifi County, adoption of meaningful youth engagement with national policy makers and prioritization of youth SRH issues in several Counties. Since the survey was not assessing any impact, we targeted all the 3,414 and any other eligible youth who consented to participate in the survey.

\section{Data collection activities}

A set of 40 questions were adopted from previous COVID-19 related studies in Kenya [23]. Six Kenyan enumerators were trained remotely on the survey instrument using Zoom. The survey instrument was piloted with young people who were not part of the Y-ACT platform. The questionnaire was then administered among the youth networks. Before administering the questionnaires, the content of the study and the eligibility criteria were explained through various platforms, including SMS, emails, and online discussions. Thereafter a link with the tool was circulated to all participants in various platforms including Y-ACT's and other social media platforms. A written online consent to participate in the study was included on the survey link, for participants to give consent prior to responding to the questions. Once the online link was circulated, a team of six research assistants (RA) followed up with phone-based interviews to urge the youth to complete the survey. The RAs also interviewed those who were not able to complete the online tool on their own. The enumerators were selected from a team that had extensive experience working with vulnerable populations.

The survey aimed to provide information on the level of knowledge on signs and symptoms of COVID-19, commonly used channels of information on COVID-19, adoption of preventive practices, and the effects of COVID-19 among the youth, focusing on health seeking behavior for SRH services and other social and economic effects of the pandemic, as informed by literature review of other epidemics/pandemics and effects on $\mathrm{SRH}$, health service delivery and socio-economic factors. The tool also covered their perceived risk, fears or concerns regarding the outbreak. (See supplementary file 1). We received expedited ethical approval for the rapid survey, to provide timely evidence that was needed to guide community engagement activities. The survey was approved by AMREF-ESRC P798/2020.

\section{Data processing and analysis}

The data was collected using an online google survey and the data exported to STATA v15 for analysis. Participants had an option of terminating the study at any time. No financial or other incentives were given for taking part in the study. The data was cleaned in preparation for descriptive analysis. All survey 
responses were tabulated by gender, age, education level to generate basic descriptive tables and tested for differences by category using chi-square tests or t-test where applicable with a significance level of 0.05 . Where applicable multivariate linear and logistic regression analysis was conducted comparing various outcome indicators with covariates such as employment status, gender, and education level.

\section{Results}

\section{Characteristics of study participants}

A total of 2,177 youth were reached through the online survey. Twenty-one (21) did not complete all the questions, hence data for a total of 2,156 youth was used for the analysis. The average age of participating youth was 26 years. Most of the respondents were aged between $25-29$ years and $74 \%$ had completed higher education. In terms of marital status, $70 \%$ were single and nearly $50 \%$ were not employed.

\section{Knowledge of COVID-19 symptoms and preventive measures}

Knowledge on symptoms of COVID-19 was generally high with most respondents being able to correctly identify an average of five symptoms of COVID-19, out of the ten examined. Female respondents were more likely to identify more symptoms correctly compared to men; $p<0.001$. High fever ( $96 \%)$, difficulty in breathing $(91 \%)$ and dry cough (84\%) were the symptoms commonly mentioned with the least being loss of taste (18\%), loss of smell (15\%) and diarrhea (12\%).

A multivariate linear regression analysis was conducted to examine whether gender, education level and employment status predicts the level of awareness of signs and symptoms measured by total scores achieved. Female respondents had on average higher levels of awareness than males in identifying signs and symptoms compared to the male respondents (Coeff: $0.36 ; \mathrm{p}<0.001, \mathrm{Cl}(0.19,0.53)$. Those with college education had higher level of awareness of identifying signs and symptoms compared to those lower levels of education (Coeff: $0.29 ; \mathrm{p}=0.03, \mathrm{Cl}(0.10,0.49)$. Consequently, young people in formal employment had higher levels of awareness of signs and symptoms compared to the unemployed (Coeff: $0.35, p=0.001, \mathrm{Cl}(0.15,0.55)$. However, those who were in self-employment had on average lower levels of awareness of identifying signs and symptoms of COVID-19 compared to those in formal employment (Coeff: $-0.15, \mathrm{p}=0.191, \mathrm{Cl}(-0.37,0.07)$.

In terms of preventive measures, the most common preventive measures mentioned were washing hands with soap and running water (98.1\%), use of hand sanitizers (95.6\%), use of mask (93.1\%), maintaining social distance of $1-2$ meters away (88\%), and staying home unless urgent (87.5\%). On average, the youth mentioned at least 11 preventive measures correctly out of the 14 examined, with no significant differences by gender. When we examined the relationship between ability to identify preventive measures using multivariate linear regression analysis, there were no associations between gender, 
education, and employment status. However, young people in formal employment had on average higher levels of awareness of preventive measures compared to those without employment: (Coeff: 0.38, $\mathrm{p}=0.037 \mathrm{Cl}(0.020 .74)$.

\section{Perception of Risk of COVID-19}

Among the young people, knowledge on who is at risk of infection of COVID-19 indicated variations. Despite nearly $64 \%$ and $60 \%$ correctly identifying that the elderly and those with weak immune are at risk of infection, only $7 \%$ of young people reported that anyone is at risk of infection. When asked what the chances were of getting infected with COVID-19, about 29\% perceived themselves being at low risk, 39\% at medium risk, less than $3 \%$ reported no risk at all. Overall, $32 \%$ reported low or no risk at all with no differences between gender. Among those who reported no or low risk, reasons for their response were: they had not travelled (43\%) or that God protects them (24\%).

We computed multiple logistic regression analysis by examining the odds of those reporting being at any risk compared to those who did not perceive themselves at risk. There were no associations between those who reported any risk with gender OR: $1.1, \mathrm{P}=0.41695 \% \mathrm{Cl}(0.89,1.30)$ and education OR: 0.85 , $\mathrm{P}=0.17495 \% \mathrm{Cl}(0.68,1.1)$. However, those in formal employment and self-employed were less likely to report any risk compared to the unemployed: OR: $0.77, \mathrm{P}=0.028,95 \% \mathrm{Cl}(0.62,0.97) ; \mathrm{OR} 0.76, \mathrm{P}=0.033$, $95 \% \mathrm{Cl}(0.58,0.97)$ respectively.

Over $90 \%$ ( $n=2112)$ of the youth reported that they would be very concerned if they became infected with Corona virus (figure 1). Similarly, they reported higher levels of concern $(96 \% n=2115)$ if any of their household members was infected with the virus.

\section{Sources of information about COVID-19}

Young people were asked how often they used various sources of information to stay informed about the COVID-19 virus. The response was on a scale of 1-4 with 1 being none, 2 - rarely, 3 - sometimes and 4 - all the times. Table 4 shows the proportion of young people who mentioned using each of the channels as sources of information for COVID-19. The most common sources which were used all the time were social media sources (67\%), followed by television programs (62\%) and friends and internet at $49 \%$ percent each. The least used channels were community health workers (8\%), church (5\%), pharmacy and community meetings at $5 \%$ and $3 \%$ respectively.

\section{Adoption of preventive behaviors}

To assess adoption of preventive behaviors, young people were asked what they are doing differently since they started receiving messages about COVID-19. Figure 2 shows that most young people were adopting behavior necessary to slow down the infection. For example, nearly all respondents (99\%) avoided unnecessary travel, $98 \%$ wash hands more frequently and $97 \%$ avoid crowded places. Among those that reported that they do not always wash hands with soap and water more frequently $n=397$, the 
main barriers were: cannot afford extra water $(21.4 \%)$, or there was no water in community $(16.4 \%)$ or in the house $16.1 \%$. Apparently 192 of them reported no barrier at all, representing $48 \%$.

The other important preventive measure was use of masks, with $98 \%$ reported wearing masks while going out. When asked the type of mask they owned, $42 \%$ reported using surgical mask with more female reporting using such masks compared to men $p=0.009$ while majority (67\%) use cloth masks. The key barriers to wearing of masks among those who mentioned they do not own any were: ability to afford (51\%), not knowing where to get one (36\%) and discomfort at $29 \%$. Only $7 \%$ reported that they do not think it works or they were not allowed to wear one (2\%). The third preventive measure was use of hand sanitizer if respondents cannot access water and soap. This was reported among $80 \%$ of the youth. Among those who did not use hand sanitizer $(n=420), 87 \%$ reported that they do not use it because it is very expensive, $20 \%$ said they were not available in shops and less than $2 \%$ said they do not think it works.

\section{COVID-19 effects on health care seeking behaviors and social economic effects}

Young people were asked what health care services or medicines they were not able to access due to the COVID-19 pandemic. There were generally very low reported levels of inability to access certain services linked to SRH. For example, only $4 \%$ of the female reported being unable to access E-pills and other contraceptives, $5 \%$ were not able to access sanitary towels while $8 \%$ were not able to access condoms. Additionally, only less than $5 \%$ were not able to access anti-retroviral drugs (ARV) while $8 \%$ were not able to access drugs to relieve anxiety or depression.

In terms of social effects, $41 \%$ reported seeing friends less or family less (39\%). Nearly a third reported living in fear, while $27 \%$ reported feeling stressed. Less than $3 \%$ reported experiencing some form of stigma. However, COVID-19 was reported to have affected the youth economically with half of them reporting significant reduction in income with more male reporting compared to female $p<0.001$. About a third reported increased expense in their house or increased food prices and less than $23 \%$ reported loss of job. Of those with no form of employment, $23 \%$ were more likely to report complete loss of job compared to those with any form of employment (15\%), $p<0.001$.

\section{Discussion}

Young people are a critical driver of economic and social change. Regardless of the nomenclature used, young people comprise the largest population in the developing world and comprise $27 \%$ of the world's population $[24,25]$. Despite being considered a healthy group, young people are at higher risk of sexual and reproductive morbidity and mortality [26-29]. They are also more likely to experience difficulties in obtaining specific and timely SRH services and sexuality education, limiting their ability to realize SRH benefits. In Kenya, young people below the age of 25 constitute $66 \%$ of the total population [30] and exhibit poor reproductive health outcomes such as teenage pregnancies, unmet needs for contraceptive and early sexual debut [31]. To facilitate mechanisms of engaging young people in the COVID-19 response, we conducted a survey to provide information on the level of knowledge on symptoms, 
commonly used channels of information about COVID-19, adoption of preventive practices, and the effects of COVID-19 on health seeking behavior for SRH services and other social and economic effects of the pandemic.

The survey showed high levels of knowledge on COVID-19 symptoms and prevention practices. Close to $90 \%$ of youth can correctly identify at least three symptoms of COVID-19. Of the 14 infection prevention methods listed, females were able to correctly identify $71 \%$ of them and males identified $73 \%$, with no significant differences in the preventive methods mentioned. High levels of knowledge on symptoms and prevention strategies could be linked to two main reasons. First, the survey was conducted four weeks into the pandemic where the youth had been exposed to various messages on the Y-ACT and other online platforms. The second reason could be linked to use of social media platforms with $66 \%$ reporting always using the media to access COVID-19 related information. Findings from a similar study showed that only $45 \%$ had received information on COVID-19 using social media but were not necessarily trusted sources[23]. Use of influencers and experts on social media platforms would provide accurate information on COVID-19 and help shape the behavior of young people. This would have ripple effects as nearly half also mentioned using friends as sources of information. The high levels of knowledge on COVID-19 symptoms and prevention practices may lead to sustained adoption of preventive behaviors as was shown during the SARS outbreaks where high knowledge levels were linked to better adoption of precautionary practices, while clear communication and provision of updated information helped improve vigilance and preparedness during the pandemic[32].

Another important area of focus for the response team is messaging around perceived risks. Our survey shows that $31 \%$ of the youth ( 1 in every 3 ) perceive themselves as being at low or no risk of getting infected with COVID-19. These levels varied with a previous study conducted in the informal settlement of Nairobi where about a third of participants felt they were at high risk of infection[23]. The low risk was associated with having no history of travel and the believe that God will protect them. Although history of travel is still a potential risk factor, breaking the community transmission would require strengthening messaging to address myths and misconceptions on risk of infection.

In terms of practice, majority of the youth begun adopting positive behavior practices to avoid infection since they started receiving messages on COVID-19. For example, the youth were avoiding unnecessary travel (99\%), washing hands more frequently $(98 \%)$ and using masks $(98 \%)$. The few who were not practicing such behaviors reported lack of water or soap, the cost of masks, discomfort while wearing mask and costs of sanitizers as deterrent to practicing preventive behaviors. A previous survey conducted two weeks prior to this, confirms that households are already performing risk reduction behaviors including increased hand washing with soap where possible, use of hand sanitizer, and staying home more[23]. Although young people reported practicing preventive behaviors, additional efforts should focus on how to sustain these behaviors on hygiene and social distancing. The response team should focus on ensuring that as the pandemic evolves, they strengthen quality assurance of preventive equipment such as cloth masks (that are being used widely). The response team and the government 
should also provide guidance on proper use and re-use of cloth masks, including cloth specifications to ensure effectiveness of the masks in infection prevention.

Finally, our study has illustrated the effect of COVID-19 on the health seeking patterns, social and economic effects. Four main emerging considerations are important. First, there were low proportions of respondents reporting inability to access contraceptives during the pandemic period (4.1\%) and condoms at (8.4\%). Access to Anti-retroviral treatment and HIV/AIDS counselling was relatively low at $2.3 \%$ and $4.7 \%$ respectively. This could be associated with the fact that perhaps young people are not necessarily frequent users of SRH services. Despite low numbers reporting inability to access SRH services, there is need for innovative platforms to ensure access to health services especially SRH for the youth, in the wake of the movement restrictions. Previous outbreaks indicate that when health systems are overwhelmed, mortality from vaccine-preventable and other treatable conditions are likely to increase drastically. For example, during the 2014-2015 Ebola outbreak, there was increased mortality caused by measles, malaria, HIV/AIDS, and tuberculosis attributable to health system failures. Deaths from these preventable conditions exceeded those from Ebola [20]. Other studies which examined the effect of Ebola on SRH showed a decline on use of family planning services [33].

The second consideration is that government guidelines and protocols on continuity of health services need to be disseminated widely especially among young people to assure them of their safety and available services. This is in line with the World Health Organization (WHO) operational planning guidelines that encourages countries to identify essential services, including routine vaccination; reproductive health services such as care during pregnancy and childbirth; management of mental health conditions and infectious diseases like HIV, malaria and TB, among others [34]. These services require prioritization by ensuring strategic shifts of limited resources to provide maximum benefit for the population[34]. Prioritization of services should be combined with a system that can track SRH service needs and use in different population segments to ensure targeted strategies are deployed not only to provide services but also support dissemination and messaging around continuity of services. This is important especially among vulnerable populations such as young girls. Deploying effective measures early will help avoid long term consequences such as increased incidence of HIV infections and unwanted pregnancies.

The third consideration is associated with other social effects. The youth reported seeing friends and family less, but more importantly about a third reported living in fear, and a quarter feeling more stressed. This compounded with the fact that only $8 \%$ reported inability to access stress related medicines means that appropriate measures are needed to invest more in mental health programmes and psychosocial support during pandemics. Similar to the Ebola epidemic of 2014-2016, COVID-19 is expected to cause anxiety, depression and post-traumatic stress disorders, because of various factors, including physical distancing, stigma and discrimination, and job losses in many settings hardest hit by the pandemic[35]. Stakeholders need to explore the value of digital platforms as well as toll-free help lines in view of low digital literacy and low smartphone penetration in some areas, to ensure that people stay connected with their families and friends. Reporting and tracking of emerging mental health issues and responses being 
offered to the youth is also necessary. Investments that focus on effective social networks can be instrumental in supporting young people during the pandemic period.

The fourth consideration that requires strategic intervention is the youth reporting loss of income, increased house expenses, cost of food and loss of jobs. Again, drawing from the 2014 Ebola outbreak, combining cash injections and skills training can stimulate employment and entrepreneurship. Government and partners therefore need to develop policies that will enhance resilience and recovery of small and medium sized enterprises, many of which are income channels for majority of youth. Further, there is need for integration of skills development including alternative entrepreneurial skills within social protection programs. Additionally, expanding digital job opportunities for the youth can be a good avenue for alternative sources of income.

Several limitations and opportunities are worth mentioning. First our study was among the first that examined the effect of COVID-19 among the young people in Kenya. This provided us with an opportunity to assess the trajectory needed to advance interventions to support the national response. Although we do not have data disaggregated by urban or rural, we had some respondents completing online studies while a substantial percentage were interviewed on phone after indicating inability to complete the survey online. In addition, our survey included all 47 counties in Kenya indicating wider geographical coverage and inclusion of those who would have been disenfranchised by online access.

The second set of limitation is that our survey did not explore reasons for barriers to use of SRH health services during the pandemic and potential solutions. Further, while the study sought information on access to contraception and ARVs, we did not necessarily sample only sexually active youth, but rather all youth in general hence the responses to this questions might have been skewed to youth who did not necessarily need the services. Further studies that reach a wider demography of youth in Kenya are needed, as well as qualitative experience of barriers and opportunities to improve access to SRH services during this period. However, by using rapid quantitative online survey, the study was able to provide guidance on appropriate information channels to reach young people as well as potential interventions needed to reach various youth population segments.

\section{Conclusion}

Our study revealed high knowledge of COVID-19 symptoms, preventive strategies, and adoption of preventive practices. However, low report on use of SRH services and the socioeconomic effects of the pandemic suggest that risk communication should emphasize on continuity of health services and ways of implementing innovative interventions to meet the health and socioeconomic needs of the youth to minimize the long-term consequences of the pandemic. Strategies to sustain behaviors positively adopted among young people will be critical to reduce the spread of COVID-19. Lastly, we recommend tapping into the young people's network to be ambassadors of behavior change and support dissemination of COVID-19 related information as they are a huge population segment spread across the 
country. Armed with proper personal protective equipment and information, young people can support home-based care and ensure health facilities are not overwhelmed.

\section{Declarations}

Ethics approval and consent to participate: We received expedited ethical approval for the rapid survey due to the urgent nature of the pandemic response measures and need for information to guide community engagement activities. The survey was approved by Amref Ethics and Scientific Research Committee. Our approval reference number is: AMREF-ESRC P798/2020. Regarding consent to participate, a written online consent to participate in the study was included on the survey link, for participants to give consent prior to responding to the questions.

Consent for publication: Consent is hereby given for publication of this manuscript.

Availability of data and materials: All data and materials used in this study are available, and have been safely stored by the Principle Investigator.

Competing interests: There are no competing interests related to this study.

Funding: The study was part of the youth online engagement work by Y-ACT, Youth in Action in Kenya project, supported by the Bill \& Melinda Gates Foundation.

\section{Authors' contributions: N/A}

Acknowledgements: We acknowledge the research assistants and study support team for their contribution to this research: (in alphabetical order) Clayton Opiyo, Gloria Nyanja, Hellen Ochola, Jane Musyoka, Joyce Mbuthia, Khadija Mohamed, LilianMaria Wambui, Lucy Kerubo, Shawn Ambunya, Steve Kagia, Valarie Musavi, Willah Simiyu.

Authors' information (optional): Amref Health Africa and Population Council

\section{References}

1. Zaki, A.M., et al., Isolation of a novel coronavirus from a man with pneumonia in Saudi Arabia. N Engl J Med, 2012. 367(19): p. 1814-20.

2. Chen, G., et al., Clinical and immunologic features in severe and moderate Coronavirus Disease 2019. J Clin Invest, 2020.

3. Drosten, C., et al., Identification of a novel coronavirus in patients with severe acute respiratory syndrome. N Engl J Med, 2003. 348(20): p. 1967-76.

4. Chen, T., et al., Clinical characteristics of 113 deceased patients with coronavirus disease 2019: retrospective study. BMJ, 2020. 368: p. m1091. 
5. Rota, P.A., et al., Characterization of a novel coronavirus associated with severe acute respiratory syndrome. Science, 2003. 300(5624): p. 1394-9.

6. Adhikari, S.P., et al., Epidemiology, causes, clinical manifestation and diagnosis, prevention and control of coronavirus disease (COVID-19) during the early outbreak period: a scoping review. Infect Dis Poverty, 2020. 9(1): p. 29.

7. Li, Q., et al., Early Transmission Dynamics in Wuhan, China, of Novel Coronavirus-Infected Pneumonia. N Engl J Med, 2020. 382(13): p. 1199-1207.

8. WHO. WHO. Novel Coronavirus-China. 2020. https://www.who.int/csr/don/12-january-2020-novelcoronavirus-china/en/. Accessed 6 April 2020. 2020.

9. COVID-19, G.E.E.o. Congressional Research Service https://crsreports.congress.gov , R46270, Updated March 26, 2020. 2020.

10. Gilbert, M., et al., Preparedness and vulnerability of African countries against importations of COVID19: a modelling study. Lancet, 2020. 395(10227): p. 871-877.

11. Massinga Loembe, M., et al., COVID-19 in Africa: the spread and response. Nat Med, 2020. 26(7): p. 999-1003.

12. MoH. First Case Of Coronavirus Disease Confirmed In Kenya; http://www.health.go.ke/first-case-ofcoronavirus-disease-confirmed-in-kenya/ 2020.

13. NERC, COVID-19 OUTBREAK IN KENYA DAILY SITUATION REPORT - 51. 2020.

14. Kenya, R.o., 2019 KENYA POPULATION AND HOUSING CENSUS. 2019.

15. Development, N.C.f.P.a., Youth Bulge in Kenya: A Blessing or a Curse: Policy Brief. 2017.

16. MoH, National Guidelines for Provision of Adelescent and Youth Friendly Srvices In Kenya. 2016.

17. Kenya National Bureau of Statistics, M.o.H., National AIDS Control Council, KEMRI, NCPAD, DHS Program, ICF International, Kenya Demographic and Health Survey 2014. 2015. 2015.

18. Health, M.o., KENYA HIV ESTIMATES. 2018, National AIDS CONTROL COUNCIL.

19. NCPD, Youth Bulge in Kenya: A Blessing or a Curse. 2017, National Council for Population and Development.

20. Elston, J.W., et al., The health impact of the 2014-15 Ebola outbreak. Public Health, 2017. 143: p. 6070.

21. Parpia, A.S., et al., Effects of Response to 2014-2015 Ebola Outbreak on Deaths from Malaria, HIV/AIDS, and Tuberculosis, West Africa. Emerg Infect Dis, 2016. 22(3): p. 433-41.

22. UNWOMEN. https://data.unwomen.org/resources/covid-19-emerging-gender-data-and-why-itmatters. 2020.

23. Austrian K, et al., COVID-19 related knowledge, attitudes, practices and needs of households in informal settlements in Nairobi, Kenya. [Submitted]. Bull World Health Organ. E-pub: 6 April 2020. doi: http://dx.doi.org/10.2471/BLT.20.260281. 2020. 
24. UN, United Nations, World Population Prospects: The 2010 Revision New York: Department of Social Affairs, Population Division, United Nations, 2011. 2011.

25. UNICEF, Adolescence. An Age of Opportunity, United Nations International Children's Emergency Fund. New York: 2011.

26. Gore, F.M., et al., Global burden of disease in young people aged 10-24 years: a systematic analysis. Lancet, 2011. 377(9783): p. 2093-102.

27. Halcon, L., et al., Adolescent health in the Caribbean: a regional portrait. Am J Public Health, 2003. 93(11): p. 1851-7.

28. Viner, R.M., et al., 50-year mortality trends in children and young people: a study of 50 low-income, middle-income, and high-income countries. Lancet, 2011. 377(9772): p. 1162-74.

29. Patton, G.C., et al., Global patterns of mortality in young people: a systematic analysis of population health data. Lancet, 2009. 374(9693): p. 881-92.

30. National Council for Population and Development (NCPD), Central Bureau of Statistics (CBS) (Office of the Vice President and Ministry of Planning and National Development) [Kenya], and Macro International Inc. (MI). 1999. Kenya Demographic and Health Survey 1998. Calverton, Maryland: NDPD, CBS, and MI. 1999.

31. Kenya National Bureau of Statistics, M.o.H., National AIDS Control Council, KEMRI, NCPAD, DHS Program, ICF International „Kenya Demographic and Health Survey 2014. 2015.

32. Yap, J., et al., Knowledge, attitudes and practices towards pandemic influenza among cases, close contacts, and healthcare workers in tropical Singapore: a cross-sectional survey. BMC Public Health, 2010. 10: p. 442.

33. Camara, B.S., et al., Effect of the 2014/2015 Ebola outbreak on reproductive health services in a rural district of Guinea: an ecological study. Trans R Soc Trop Med Hyg, 2017. 111(1): p. 22-29.

34. WHO, Maintaining essential health services: operational guidance for the COVID-19 context. Interim guidance 1 June 2020. 2020.

35. Semo, B.W. and S.M. Frissa, The Mental Health Impact of the COVID-19 Pandemic: Implications for Sub-Saharan Africa. Psychol Res Behav Manag, 2020. 13: p. 713-720.

\section{Tables}

Table 1: Characteristics of the study respondents 


\begin{tabular}{|c|c|c|c|c|c|c|c|}
\hline \multirow{2}{*}{ Characteristics } & Female & & Male & & Total & & $\mathrm{P}$ values \\
\hline & 1083 & (\%) & 1073 & (\%) & 2156 & (\%) & \\
\hline Average age (SD) & 25.4 & (3.6) & 26.8 & (3.7) & 26.1 & $(3.7)$ & $<0.001$ \\
\hline Age distribution & 1083 & & 1073 & & 2156 & & \\
\hline $18-19$ & 41 & $(3.8)$ & 15 & $(1.4)$ & 56 & $(2.6)$ & \multirow{4}{*}{$<0.001$} \\
\hline $20-24$ & 445 & $(41.1)$ & 293 & $(27.3)$ & 738 & $(34.2)$ & \\
\hline $25-29$ & 439 & $(40.5)$ & 485 & $(45.2)$ & 924 & $(42.9)$ & \\
\hline $30-35$ & 158 & $(14.6)$ & 280 & $(26.1)$ & 438 & $(20.2)$ & \\
\hline University & 1083 & & 1073 & & 2156 & & \\
\hline Completed Primary School & 14 & $(1.3)$ & 7 & $(0.7)$ & 21 & $(0.9)$ & \multirow{4}{*}{0.013} \\
\hline Completed Secondary School & 111 & $(10.2)$ & 73 & $(6.7)$ & 184 & $(8.5)$ & \\
\hline Incomplete Higher Education & 172 & (15.9) & 179 & (16.5) & 351 & (16.3) & \\
\hline Completed Higher Education & 786 & $(72.6)$ & 814 & $(75.2)$ & 1600 & $(74.2)$ & \\
\hline Marital status & 1083 & & 1073 & & 2156 & & \\
\hline Married & 221 & $(20.4)$ & 349 & (32.5) & 570 & $(26.4)$ & \multirow{4}{*}{$<0.001$} \\
\hline Separated & 14 & $(1.3)$ & 13 & $(1.2)$ & 27 & $(1.2)$ & \\
\hline Single & 823 & $(76.0)$ & 685 & $(63.9)$ & 1508 & $(70.0)$ & \\
\hline No response & 25 & $(2.3)$ & 26 & $(2.4)$ & 51 & $(2.4)$ & \\
\hline Employment status & 1083 & & 1073 & & 2156 & & \\
\hline No employment & 606 & $(55.9)$ & 465 & $(43.3)$ & 1071 & $(49.7)$ & \multirow{4}{*}{$<0.001$} \\
\hline Self employed & 285 & $(26.3)$ & 327 & $(30.5)$ & 612 & $(28.4)$ & \\
\hline Formal employment & 160 & $(14.8)$ & 257 & $(23.9)$ & 417 & $(19.3)$ & \\
\hline No response & 32 & $(2.9)$ & 24 & $(2.2)$ & 56 & $(2.6)$ & \\
\hline
\end{tabular}

Table 2: Knowledge of symptoms and preventive measures 


\begin{tabular}{|c|c|c|c|c|c|c|c|}
\hline $\begin{array}{l}\text { \% reporting the following } \\
\text { symptoms }\end{array}$ & $\begin{array}{c}\text { Female } \\
\mathrm{N}=1083\end{array}$ & (\%) & $\begin{array}{c}\text { Male } \\
\mathrm{N}=1073\end{array}$ & (\%) & $\begin{array}{c}\text { Total } \\
\mathrm{N}=2156\end{array}$ & (\%) & p value \\
\hline High Fever above 38 & 1053 & (97.2) & 1014 & $(94.5)$ & 2067 & $(95.9)$ & 0.001 \\
\hline Difficulty breathing & 988 & $(91.2)$ & 969 & $(90.3)$ & 1957 & $(90.8)$ & 0.13 \\
\hline Dry cough & 915 & $(84.5)$ & 885 & $(82.5)$ & 1800 & $(83.5)$ & 0.209 \\
\hline Headache & 703 & $(64.9)$ & 678 & $(63.2)$ & 1381 & $(64.1)$ & 0.404 \\
\hline Sore Throat & 652 & $(60.2)$ & 578 & $(53.9)$ & 1230 & $(57.1)$ & 0.003 \\
\hline Tiredness/fatigue & 558 & $(51.5)$ & 480 & $(44.7)$ & 1038 & $(48.1)$ & 0.002 \\
\hline Body Ache & 343 & $(31.7)$ & 324 & $(30.2)$ & 667 & $(30.9)$ & 0.459 \\
\hline Loss of taste & 218 & (20.1) & 160 & (14.9) & 378 & $(17.5)$ & 0.001 \\
\hline Loss of smell & 186 & $(17.2)$ & 143 & $(13.3)$ & 329 & $(15.3)$ & 0.013 \\
\hline Diarrhea & 143 & $(13.2)$ & 118 & $(11.0)$ & 261 & $(12.1)$ & 0.116 \\
\hline $\begin{array}{l}\text { Average no of signs (0-10) } \\
\text { (SD) }\end{array}$ & 5.3 & $(1.9)$ & 4.9 & $(1.9)$ & 5.1 & $(1.9)$ & $<0.001$ \\
\hline $\begin{array}{l}\text { \% reporting the following } \\
\text { ways of preventing COVID- } \\
19\end{array}$ & 1083 & (\%) & 1073 & (\%) & 2156 & (\%) & \\
\hline $\begin{array}{l}\text { Wash hands with soap and } \\
\text { running water }\end{array}$ & 1069 & $(98.7)$ & 1046 & $(97.5)$ & 2115 & $(98.1)$ & 0.038 \\
\hline Use hand sanitizer & 1042 & $(96.2)$ & 1020 & $(95.1)$ & 2062 & $(95.6)$ & 0.19 \\
\hline Wear masks & 1018 & $(94.0)$ & 989 & $(92.2)$ & 2007 & $(93.1)$ & 0.095 \\
\hline $\begin{array}{l}\text { Stand 1-2 meters away } \\
\text { from people }\end{array}$ & 946 & $(87.3)$ & 952 & $(88.7)$ & 1898 & $(88.0)$ & 0.326 \\
\hline Stay home unless urgent & 961 & $(88.7)$ & 925 & $(86.2)$ & 1886 & $(87.5)$ & 0.076 \\
\hline Do not touch face & 956 & $(88.3)$ & 921 & $(85.8)$ & 1877 & $(87.1)$ & 0.092 \\
\hline Do not shake hands & 955 & $(88.2)$ & 935 & $(87.1)$ & 1890 & $(87.7)$ & 0.462 \\
\hline Use digital money & 867 & $(80.1)$ & 838 & $(78.1)$ & 1705 & $(79.1)$ & 0.264 \\
\hline $\begin{array}{l}\text { Do not go to } \\
\text { weddings/funerals }\end{array}$ & 771 & $(71.2)$ & 739 & (68.9) & 1510 & $(70.0)$ & 0.24 \\
\hline $\begin{array}{l}\text { Do not go to } \\
\text { church/mosque }\end{array}$ & 763 & $(70.5)$ & 730 & $(68.0)$ & 1493 & $(69.2)$ & 0.224 \\
\hline $\begin{array}{l}\text { Reduce the number of } \\
\text { people they come to contact } \\
\text { with }\end{array}$ & 723 & $(66.8)$ & 713 & $(66.4)$ & 1436 & $(66.6)$ & 0.879 \\
\hline $\begin{array}{l}\text { Avoid public } \\
\text { transport/travelling }\end{array}$ & 690 & $(63.7)$ & 645 & $(60.1)$ & 1335 & $(61.9)$ & 0.085 \\
\hline Scrub/clean surfaces & 711 & $(65.7)$ & 584 & $(54.4)$ & 1295 & $(60.1)$ & $<0.001$ \\
\hline $\begin{array}{l}\text { Get tested for coronavirus } \\
\text { (COVID-19) }\end{array}$ & 459 & $(42.4)$ & 527 & $(49.1)$ & 986 & $(45.7)$ & 0.002 \\
\hline Average scores (0-14) (SD) & 11.0 & $(3.3)$ & 10.7 & (3.5) & 10.9 & (3.4) & 0.104 \\
\hline Linear regression model & \multicolumn{3}{|c|}{ No of observations $=2156$} & & $=0.0000$ & \multicolumn{2}{|c|}{$\begin{array}{l}\text { R Squared= } \\
0.0241\end{array}$} \\
\hline $\begin{array}{l}\text { Number of signs \& } \\
\text { symptoms }\end{array}$ & \multicolumn{2}{|c|}{ Coefficient } & \multicolumn{2}{|l|}{$P$ value } & \multicolumn{3}{|c|}{ Confidence interval } \\
\hline Gender (ref: Female) & \multicolumn{2}{|l|}{0.36} & \multicolumn{2}{|l|}{$<0.001$} & \multicolumn{3}{|c|}{$0.19,0.53$} \\
\hline $\begin{array}{l}\text { Education; (ref: College } \\
\text { education }\end{array}$ & \multicolumn{2}{|l|}{0.296} & \multicolumn{2}{|l|}{0.008} & \multicolumn{3}{|c|}{$0.070, \quad 0.46$} \\
\hline \multicolumn{8}{|l|}{$\begin{array}{l}\text { Employment status: ref: no } \\
\text { employment }\end{array}$} \\
\hline Formal employment & \multicolumn{2}{|l|}{0.35} & \multicolumn{2}{|l|}{0.001} & \multicolumn{3}{|c|}{$0.15,0.55$} \\
\hline
\end{tabular}




\begin{tabular}{|l|l|l|l|} 
Self-employed & -0.15 & 0.191 & $-0.37,0.07$ \\
\hline Linear regression model & $\begin{array}{l}\text { No of } \\
\text { observations } \\
\mathbf{= 2 1 5 6}\end{array}$ & $\mathbf{P}>\mathbf{F}=\mathbf{0 . 0 0 0 0}$ & R Squared= $\mathbf{0 . 0 2 4 1}$ \\
\hline $\begin{array}{l}\text { No of preventive measures } \\
\text { identified }\end{array}$ & $\begin{array}{l}\text { \#of observations } \\
\mathbf{2} \mathbf{2 1 5 6}\end{array}$ & $\mathbf{P}>\mathbf{F}=\mathbf{0 . 0 5 3 6}$ & $\mathbf{R}$ Squared= $\mathbf{0 . 0 0 4 8}$ \\
\hline Gender (ref: Female) & -0.27 & 0.069 & $-0.021,0.57$ \\
\hline $\begin{array}{l}\text { Education; (ref: College } \\
\text { education }\end{array}$ & 0.10 & 0.543 & $-0.24,0.46$ \\
\hline $\begin{array}{l}\text { Employment status: ref: no } \\
\text { employment }\end{array}$ & & & \\
\hline Formal employment & 0.38 & 0.037 & 0.020 .74 \\
\hline Self-employed & 0.022 & 0.912 & $-0.37,0.41$ \\
\hline
\end{tabular}

Table 3: Perception on those at risk of COVID-19 infections 


\begin{tabular}{|c|c|c|c|c|c|c|c|}
\hline $\begin{array}{l}\text { \% reporting the } \\
\text { following are at risk }\end{array}$ & $\begin{array}{c}\text { Female } \\
\mathrm{n}=1083\end{array}$ & (\%) & $\begin{array}{c}\text { Male } \\
\mathrm{n}=1073\end{array}$ & (\%) & $\begin{array}{c}\text { Total } \\
\mathrm{n}=2156\end{array}$ & (\%) & P value \\
\hline $\begin{array}{l}\text { Elderly/over 50/over } \\
60\end{array}$ & 681 & $(62.9)$ & 692 & $(64.5)$ & 1373 & $(63.7)$ & 0.437 \\
\hline $\begin{array}{l}\text { Sick/weak immune } \\
\text { systems }\end{array}$ & 657 & $(60.7)$ & 631 & $(58.8)$ & 1288 & $(59.7)$ & 0.379 \\
\hline People with TB & 438 & $(40.4)$ & 444 & $(41.4)$ & 882 & $(40.9)$ & 0.658 \\
\hline People with HIV & 424 & $(39.2)$ & 438 & $(40.8)$ & 862 & $(40.0)$ & 0.429 \\
\hline Pregnant women & 383 & $(35.4)$ & 302 & $(28.1)$ & 685 & $(31.8)$ & $<0.001$ \\
\hline Children & 278 & $(25.7)$ & 252 & $(23.5)$ & 530 & $(24.6)$ & 0.239 \\
\hline Men & 125 & $(11.5)$ & 127 & $(11.8)$ & 252 & $(11.7)$ & 0.832 \\
\hline $\begin{array}{l}\text { People in cold } \\
\text { countries }\end{array}$ & 114 & $(10.5)$ & 131 & $(12.2)$ & 245 & $(11.4)$ & 0.218 \\
\hline $\begin{array}{l}\text { Adolescents and } \\
\text { youth }\end{array}$ & 109 & $(10.1)$ & 122 & $(11.4)$ & 231 & $(10.7)$ & 0.327 \\
\hline Women & 93 & $(8.6)$ & 88 & $(8.2)$ & 181 & $(8.4)$ & 0.747 \\
\hline Everyone & 77 & $(7.1)$ & 76 & $(7.1)$ & 153 & $(7.1)$ & 0.981 \\
\hline $\begin{array}{l}\text { Dot know/ no } \\
\text { response }\end{array}$ & 6 & $(0.6)$ & 10 & $(0.9)$ & 16 & $(0.7)$ & 0.307 \\
\hline $\begin{array}{l}\text { \% reporting that they } \\
\text { are at }\end{array}$ & 1062 & & 1048 & & 2110 & & \\
\hline Low risk & 322 & $(30.3)$ & 289 & (27.6) & 611 & (29.0) & \\
\hline Medium risk & 406 & $(38.2)$ & 414 & $(39.5)$ & 820 & $(38.9)$ & \\
\hline High risk & 267 & $(25.1)$ & 288 & $(27.5)$ & 555 & $(26.3)$ & 0.467 \\
\hline No Risk & 29 & $(2.7)$ & 27 & $(2.6)$ & 56 & $(2.7)$ & \\
\hline $\begin{array}{l}\text { Do not know, no } \\
\text { response }\end{array}$ & 38 & $(3.6)$ & 30 & $(2.9)$ & 68 & $(3.2)$ & \\
\hline Low or no risk & 351 & $(33.1)$ & 316 & $(30.2)$ & 667 & $(31.6)$ & 0.137 \\
\hline $\begin{array}{l}\text { Reason for perceived } \\
\text { low risk }\end{array}$ & 351 & $(\%)$ & 316 & $(\%)$ & 667 & $(\%)$ & \\
\hline I am young & 25 & $(7.1)$ & 38 & $(12.0)$ & 63 & $(9.4)$ & 0.031 \\
\hline God protects me & 74 & $(21.1)$ & 89 & $(28.2)$ & 163 & $(24.4)$ & 0.034 \\
\hline $\begin{array}{l}\text { The hot } \\
\text { weather/climate }\end{array}$ & 16 & $(4.6)$ & 28 & $(8.9)$ & 44 & $(6.6)$ & 0.025 \\
\hline $\begin{array}{l}\text { COVID is not in } \\
\text { Africa/Kenya }\end{array}$ & 1 & $(0.3)$ & 1 & $(0.3)$ & 2 & $(0.3)$ & 0.941 \\
\hline I have not travelled & 154 & $(43.9)$ & 135 & $(42.7)$ & 289 & $(43.3)$ & 0.764 \\
\hline I am not a Caucasian & 1 & $(0.3)$ & 4 & $(1.3)$ & 5 & $(0.7)$ & 0.143 \\
\hline COVID is a lie & 0 & $(0.0)$ & 1 & $(0.3)$ & 1 & $(0.1)$ & 0.292 \\
\hline $\begin{array}{l}\text { Do not know, no } \\
\text { response }\end{array}$ & 35 & $(10.0)$ & 28 & $(8.9)$ & 63 & $(9.4)$ & 0.624 \\
\hline $\begin{array}{l}\text { Logistic regression } \\
\text { model }\end{array}$ & $\begin{array}{c}\# \text { of } \\
\text { observations } \\
n=2100\end{array}$ & & & & & & \\
\hline $\begin{array}{l}\text { Perception of low or } \\
\text { no Risk }\end{array}$ & OR & $\begin{array}{c}\mathrm{P} \\
\text { value }\end{array}$ & \multicolumn{3}{|c|}{ Confidence interval } & & \\
\hline Gender (ref: Female) & 1.1 & 0.416 & \multicolumn{2}{|c|}{0.896} & \multicolumn{2}{|c|}{1.303} & \\
\hline $\begin{array}{l}\text { Education; (ref: } \\
\text { College education }\end{array}$ & 0.85 & 0.174 & \multicolumn{2}{|c|}{0.689} & \multicolumn{2}{|c|}{1.06} & \\
\hline $\begin{array}{l}\text { Employment status: } \\
\text { ref: no employment }\end{array}$ & & & & & & & \\
\hline
\end{tabular}


Formal employment

Self-employed
0.77

0.75 \begin{tabular}{|l}
0.028 \\
0.033
\end{tabular}
0.615

0.588
0.973

0.978

Table 4: Use of various channels as source of COVID-19 information

\begin{tabular}{|l|c|c|c|c|c|c|c|}
\hline $\begin{array}{l}\text { \% of reporting always } \\
\text { using the following } \\
\text { sources of information about } \\
\text { COVID-19 }\end{array}$ & $\begin{array}{c}\text { Female } \\
\mathbf{n = 1 0 7 4}\end{array}$ & $\mathbf{( \% )}$ & $\begin{array}{c}\text { Male } \\
\mathbf{n = 1 0 6 6}\end{array}$ & $\mathbf{( \% )}$ & $\begin{array}{c}\text { Total } \\
\mathbf{N = 2 1 4 0}\end{array}$ & $\mathbf{( \% )}$ & $\begin{array}{c}\text { P } \\
\text { values }\end{array}$ \\
\hline Social media & 728 & $(67.8)$ & 692 & $(64.9)$ & 1420 & $(66.4)$ & 0.164 \\
\hline Television programs/shows & 719 & $(66.9)$ & 613 & $(57.5)$ & 1332 & $(62.2)$ & $<0.001$ \\
\hline Friends & 567 & $(52.8)$ & 499 & $(46.8)$ & 1066 & $(49.8)$ & 0.011 \\
\hline Internet & 537 & $(50.0)$ & 517 & $(48.5)$ & 1054 & $(49.3)$ & 0.018 \\
\hline Radio programs/shows & 444 & $(41.3)$ & 393 & $(36.9)$ & 837 & $(39.1)$ & 0.006 \\
\hline Spouse & 270 & $(25.1)$ & 365 & $(34.2)$ & 635 & $(29.7)$ & $<0.001$ \\
\hline Government SMS's & 284 & $(26.4)$ & 282 & $(26.5)$ & 566 & $(26.4)$ & 0.884 \\
\hline Work colleagues & 182 & $(16.9)$ & 234 & $(22.0)$ & 416 & $(19.4)$ & $<0.001$ \\
\hline Acquaintances / neighbors & 134 & $(12.5)$ & 156 & $(14.6)$ & 290 & $(13.6)$ & $<0.001$ \\
\hline Posters/print advert & 163 & $(15.2)$ & 124 & $(11.6)$ & 287 & $(13.4)$ & $<0.001$ \\
\hline Books/magazines & 151 & $(14.1)$ & 111 & $(10.4)$ & 262 & $(12.2)$ & 0.008 \\
\hline Public health facility & 116 & $(10.8)$ & 135 & $(12.7)$ & 251 & $(11.7)$ & $<0.001$ \\
\hline NGO provider & 126 & $(11.7)$ & 121 & $(11.4)$ & 247 & $(11.5)$ & 0.15 \\
\hline $\begin{array}{l}\text { Public announcement with } \\
\text { megaphone }\end{array}$ & 116 & $(10.8)$ & 90 & $(8.4)$ & 206 & $(9.6)$ & $<0.001$ \\
\hline Private health clinic & 70 & $(6.5)$ & 90 & $(8.4)$ & 160 & $(7.5)$ & 0.001 \\
\hline Community health worker & 75 & $(7.0)$ & 101 & $(9.5)$ & 176 & $(8.2)$ & $<0.001$ \\
\hline Church & 67 & $(6.2)$ & 57 & $(5.3)$ & 124 & $(5.8)$ & 0.016 \\
\hline Pharmacy & 45 & $(4.2)$ & 61 & $(5.7)$ & 106 & $(5.0)$ & 0.055 \\
\hline $\begin{array}{l}\text { Community } \\
\text { meetings/spaces }\end{array}$ & 36 & $(3.4)$ & 37 & $(3.5)$ & 73 & $(3.4)$ & 0.013 \\
\hline
\end{tabular}

Table 5: Effect of COVID-19 on health, social and economic status 


\begin{tabular}{|c|c|c|c|c|c|c|c|}
\hline $\begin{array}{l}\text { \% of respondents who } \\
\text { reporting not able to access } \\
\text { the following services }\end{array}$ & $\begin{array}{l}\text { Female } \\
\mathrm{n}=1083\end{array}$ & (\%) & $\begin{array}{c}\text { Male } \\
\mathrm{n}=1073\end{array}$ & (\%) & $\begin{array}{c}\text { Total } \\
\mathrm{n}=2156\end{array}$ & (\%) & $\begin{array}{c}\mathrm{P} \\
\text { values }\end{array}$ \\
\hline $\begin{array}{l}\text { E-pills and other } \\
\text { contraceptives }\end{array}$ & 88 & $(8.1)$ & 0 & $(0.0)$ & 88 & $(4.1)$ & NA \\
\hline Sanitary towels & 117 & $(10.8)$ & 0 & $(0.0)$ & 117 & $(5.4)$ & NA \\
\hline Condoms & 26 & $(2.4)$ & 156 & $(14.5)$ & 182 & $(8.4)$ & $<0.001$ \\
\hline Anti-retroviral treatment & 19 & $(1.8)$ & 30 & $(2.8)$ & 49 & (2.3) & 0.105 \\
\hline HIV/AIDS counselling & 33 & $(3.0)$ & 69 & $(6.4)$ & 102 & $(4.7)$ & $<0.001$ \\
\hline Medicine for acute illnesses & 92 & $(8.5)$ & 124 & $(11.6)$ & 216 & $(10.0)$ & 0.018 \\
\hline $\begin{array}{l}\text { Medicine for } \\
\text { stomach/digestive problems }\end{array}$ & 73 & $(6.7)$ & 81 & (7.5) & 154 & $(7.1)$ & 0.466 \\
\hline $\begin{array}{l}\text { Medicine for diabetes/Blood } \\
\text { pressure }\end{array}$ & 30 & $(2.8)$ & 39 & (3.6) & 69 & $(3.2)$ & 0.254 \\
\hline $\begin{array}{l}\text { Refills for other regular } \\
\text { medications }\end{array}$ & 99 & $(9.1)$ & 93 & (8.7) & 192 & $(8.9)$ & 0.699 \\
\hline $\begin{array}{l}\text { Immunization/nutrition } \\
\text { services for children }\end{array}$ & 115 & $(10.6)$ & 115 & $(10.7)$ & 230 & $(10.7)$ & 0.941 \\
\hline Medicine for pre-natal care & 42 & (3.9) & 32 & $(3.0)$ & 74 & (3.4) & 0.253 \\
\hline $\begin{array}{l}\text { Medication of mental } \\
\text { health/stress depression }\end{array}$ & 69 & $(6.4)$ & 102 & (9.5) & 171 & $(7.9)$ & 0.007 \\
\hline $\begin{array}{l}\text { Other social effects: } \\
\% \text { of respondents who } \\
\text { reporting }\end{array}$ & 1083 & (\%) & 1073 & (\%) & 2156 & (\%) & $\begin{array}{c}\mathrm{P} \\
\text { values }\end{array}$ \\
\hline See friends less & 440 & $(40.6)$ & 436 & $(40.6)$ & 876 & $(40.6)$ & 0.998 \\
\hline Seeing family less & 405 & $(37.4)$ & 368 & $(34.3)$ & 773 & $(35.9)$ & 0.133 \\
\hline Stayed at home & 391 & $(36.1)$ & 319 & $(29.7)$ & 710 & (32.9) & 0.002 \\
\hline Live in fear & 326 & $(30.1)$ & 321 & $(29.9)$ & 647 & $(30.0)$ & 0.925 \\
\hline Avoid public transport & 306 & $(28.3)$ & 339 & $(31.6)$ & 645 & $(29.9)$ & 0.09 \\
\hline Increased housework & 163 & $(15.1)$ & 101 & $(9.4)$ & 264 & $(12.2)$ & $<0.001$ \\
\hline More stress & 314 & $(29.0)$ & 257 & $(24.0)$ & 571 & $(26.5)$ & 0.008 \\
\hline $\begin{array}{l}\text { Increased crime in } \\
\text { neighborhood }\end{array}$ & 108 & $(10.0)$ & 149 & $(13.9)$ & 257 & $(11.9)$ & 0.005 \\
\hline Unable to access health care & 142 & (13.1) & 113 & $(10.5)$ & 255 & $(11.8)$ & 0.064 \\
\hline $\begin{array}{l}\text { Experienced more violence } \\
\text { outside house }\end{array}$ & 47 & $(4.3)$ & 61 & (5.7) & 108 & $(5.0)$ & 0.152 \\
\hline Stigma & 23 & $(2.1)$ & 37 & $(3.4)$ & 60 & $(2.8)$ & 0.062 \\
\hline $\begin{array}{l}\text { Experienced more violence } \\
\text { inside house }\end{array}$ & 10 & $(0.9)$ & 27 & (2.5) & 37 & (1.7) & 0.004 \\
\hline Economic effects & 1083 & & 1073 & & 2156 & & \\
\hline $\begin{array}{l}\text { Significant reduction in } \\
\text { income }\end{array}$ & 464 & $(42.8)$ & 615 & $(57.3)$ & 1079 & $(50.0)$ & $<0.001$ \\
\hline Increased expense in house & 397 & $(36.7)$ & 342 & (31.9) & 739 & (34.3) & 0.019 \\
\hline
\end{tabular}




\begin{tabular}{|l|c|c|c|c|c|c|c|}
\hline Increase in food prices & 374 & $(34.5)$ & 350 & $(32.6)$ & 724 & $(33.6)$ & 0.357 \\
\hline Complete loss of job & 244 & $(22.5)$ & 250 & $(23.3)$ & 494 & $(22.9)$ & 0.671 \\
\hline $\begin{array}{l}\text { Unable to purchase sanitary } \\
\text { towel }\end{array}$ & 44 & $(4.1)$ & 12 & $(1.1)$ & 56 & $(2.6)$ & $<0.001$ \\
\hline
\end{tabular}

\section{Figures}

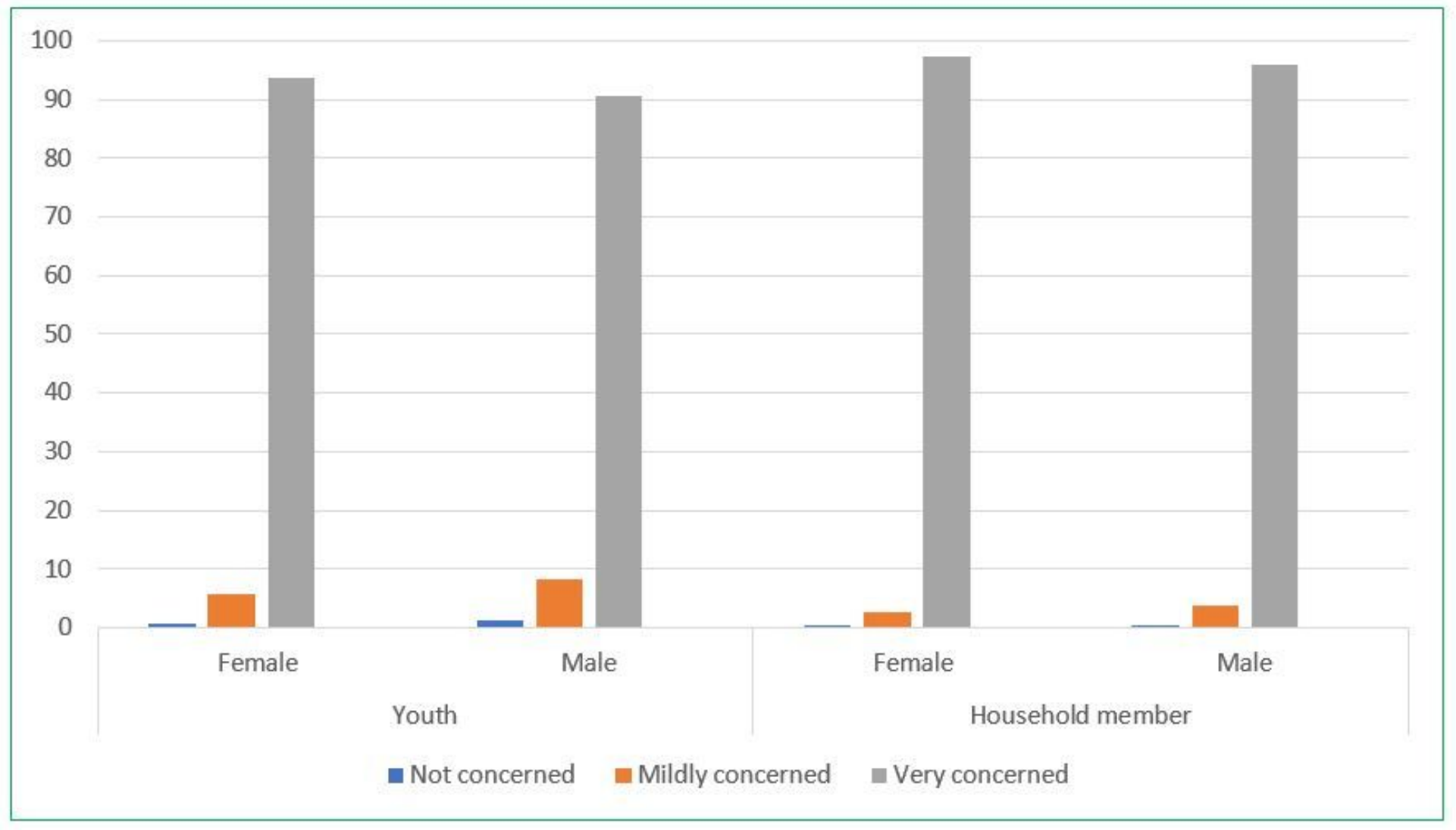

\section{Figure 1}

Level of concern among young people 
Set up more hand washing facilities

Use hand sanitser when cannot access water

Always wash with soap and water

Avoid crowded placed

Use my mask while going out

Wash hands more frequently

Avoid unnecessary travel
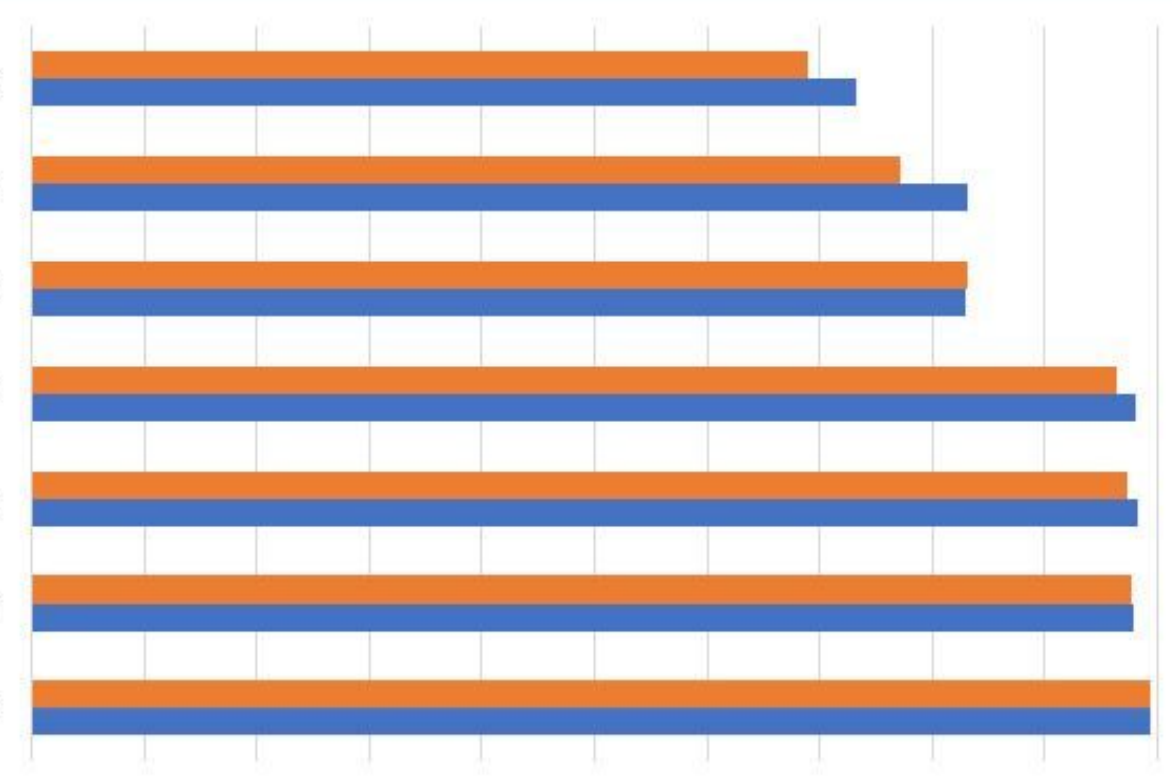

10

$20 \quad 30$

40

50

60

$70 \quad 80$

90

Figure 2

Effect of messaging on adopting preventive behaviors

\section{Supplementary Files}

This is a list of supplementary files associated with this preprint. Click to download.

- ToolCOVID19andYouthKAPStudy.docx 